\title{
Financial Evaluation of Renewable Energy Source Production in Microgrids Markets Using Probabilistic Analysis
}

\author{
A. G. Tsikalakis*,Student Member IEEE, N. D. Hatziargyriou, Senior Member, IEEE \\ *NATIONAL TECHNICAL UNIVERSITY OF ATHENS \\ SCHOOL OF ELECTRICAL \& COMPUTER ENGINEERING \\ ELECTRIC POWER DIVISION \\ 9, Iroon Polytechneiou Str., GR-15773 Zografou, Athens, GREECE \\ Tel.: +302107723696, Fax: + 302107723569, E-Mail: atsikal@power.ece.ntua.gr
}

\begin{abstract}
Restructuring of power markets has helped in the penetration of Distributed Generation (DG) in the distribution networks. Mircogrids are Low Voltage (LV) networks that usually operate interconnected with the main Medium Voltage (MV) network but, in case of emergency, can run autonomously. In such networks Renewable Energy Sources (RES) are foreseen to have rather high penetration mainly photovoltaics (PV) and small scale Wind Turbines (WTs).

One of the emerging issues is the financial evaluation of RES production so that the installation of RES is beneficial in open market conditions. In this study, the expected income for owners of wind turbine and PV is evaluated using actual prices from a spot market exchange, probability distributions of wind velocity and solar irradiation and methods of probabilistic costing analysis.
\end{abstract}

Index Terms - MicroGrids, Distributed Generation, Markets, Renewable Energy Sources, Wind Power, PV, Probabilistic Analysis

\section{INTRODUCTION}

$\mathrm{T}$ HE deregulated energy environment, among other effects, favors a gradual transition from centralized power generation to Distributed Generation (DG) sources connected at the Medium Voltage or Low Voltage side of the Distribution Network. DG sources comprise several technologies, such as Diesel Engines, Micro Turbines and Fuel Cells either in CHP operation or purely for electricity production, Photovoltaics, small Wind Turbines, etc. The capacity of the DG sources varies from few kWs to couple of

This work was supported by the E.U research project "Microgrids" (Contract No ENK 5-CT-2002-00610). The authors gratefully acknowledge the support received from the EU for this research.

Financial Evaluation of Renewable Energy Source Production in Microgrids Markets Using Probabilistic Analysis

A. G..Tsikalakis is with the School of Electrical and Computer Engineering, National Technical University of Athens, Athens, Greece, (e-mail: atsikal@power.ece.ntua.gr).

N. D. Hatziargyriou is with the School of Electrical and Computer Engineering, National Technical University of Athens, Athens, Greece, (e-mail: nh@power.ece.ntua.gr).
MWs.

Microgrids are Low Voltage (LV) networks including DG sources,storage devices, such as flywheels, energy capacitors and batteries, and controllable loads. Microgrids can operate either interconnected to the main Distribution grid, or isolated, in case of external faults. A typical Microgrid structure is shown in fig. 1.

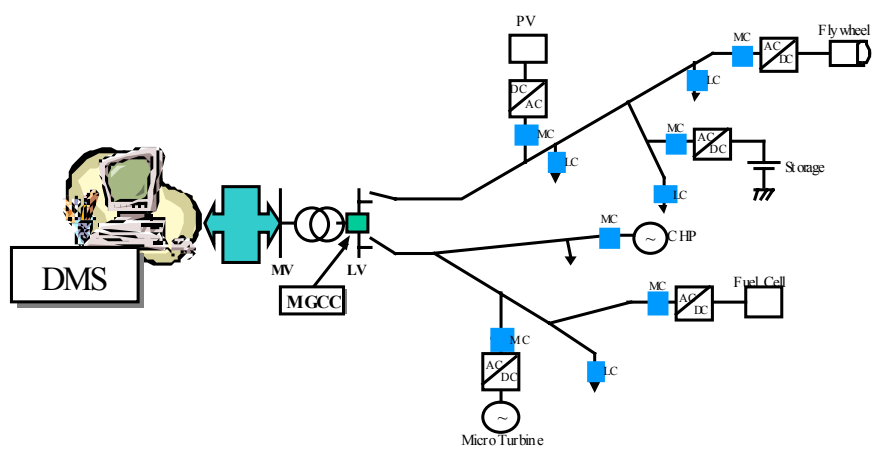

Fig 1 A typical LV Microgrid

From the grid's point of view, a Microgrid can be regarded as a controlled entity within the power system that can be operated as a single aggregated load and, given attractive remuneration, as a small source of power or ancillary services supporting the network. From a customer point of view, Microgrids similar to traditional LV distribution networks provide their thermal and electricity needs, but in addition, enhance local reliability, reduce emissions, improve power quality by supporting voltage and reducing voltage dips, and potentially lower costs of energy supply[1,2].

The Microgrid can operate as a small energy market. Which units will produce and at what level, if they are regulated, is the result of an optimization procedure that aims to maximize the value of the Microgrid. Suggested control structure for Microgrid operation is described in Section II .

RES are expected to play a significant role taking into account the current environmental commitment of several countries. Thus, evaluation of the RES production in an open market environment is necessary in order to evaluate the pay back period of the RES investments, the value of RES production for the end-users and the necessary subsidy scheme 
that would make RES investments viable. Probabilistic analysis methods developed can help in the quick evaluation of this production for long term periods.

Tariff scheme for RES varies from power market to power market. In Greece, feed-in tariffs are adopted providing 6.5 $€ \mathrm{ct} / \mathrm{kWh}$ for RES production at the interconnected power system [3] and at the $7.79 € \mathrm{ct} / \mathrm{kWh}$ island power systems [4], common for any type of RES installation. This tariff scheme can reduce the operating cost of an island power systems, as shown in [4].

Feed-in tariffs are also applied in other European Countries, like Germany [5], Portugal, Spain, Denmark etc[6],. In some of them there is distinction between wind and PV production remuneration etc. In other countries RES participate in the spot market exchange with adverse impact in the RES funding $[7,8]$.Further information on RES pricing and development can be found in [9].

In this paper, it is assumed that the energy needs of the consumers of the Microgrid are served by energy bought at the spot market prices and wind and solar energy produced locally. Using probabilistic analysis techniques, the expected financial value of wind and solar energy for the end-users of the Microgrid can be evaluated and the pay-back period with and without investment subsidies can be assessed for their investors. The methodology followed is described in Section III and a case study is presented in section IV. The results from this analysis are presented in Section V and suggestions for further work are discussed in the conclusions.

\section{Microgrids MARKETS AND CONTROL StRUCTURE}

\section{A. Microgrid control structure}

The control structure of a Microgrid consists of the following elements:

- Microgrid System Central Controller (MGCC)

- Local Controllers (MC or LC)

The Microgrid Central Controller (MGCC) is responsible for the maximization of the Microgrid's value and the optimization of its operation. It uses market prices of electricity and gas, costs and probably grid security concerns to determine the amount of power that the Microgrid should draw from the distribution system, optimizing the local production capabilities. The defined optimized operating scenario is achieved by controlling the micro-sources and controllable loads in the Microgrid by sending control signals to the MCs and LCs. This operation can be considered equivalent to the secondary control of the larger power system. In market terms, the MGCC might represent the functions of an Aggregator or Energy Service provider, who acts in the interest of one or more Microgrids. Moreover, MGCC is responsible for communication with the Distribution Management System (DMS) for receiving open market prices or the state of the Distribution network.

The Micro Source Controller (MC) takes advantage of the power electronic interface of the DG sources MCs follow the demands from the MGCC, when connected to the power grid, and perform local optimization of the DG active and reactive power production, and fast load tracking in isolated operation.
Local Load Controllers (LC) installed at the controllable loads, provide load control capabilities following orders from the MGCC for load management. In [11] decentralized control is described based on Multi-Agent Systems.

\section{B. Information exchange within a Microgrid}

The information exchange within a typical Microgrid is as follows: Every m minutes, e.g. 15 minutes, each DG source bids for production for the next hour in m minutes intervals. These bids are based on the energy prices in the open market and the operating costs of the DG units plus the profit of the DG owner. The MGCC optimizes the Microgrid operation according to the open market prices, the bids received by the DG sources and the forecasted loads and sends signals to the MCs of the DG sources to be committed and, if applicable, to determine the level of their production. In this case, the MGCC optimizes operation based on DG sources and load bids and sends dispatch signals to both the MCs and LCs. Fig. 2 shows the information exchange flow in a typical Microgrid operating under such conditions.

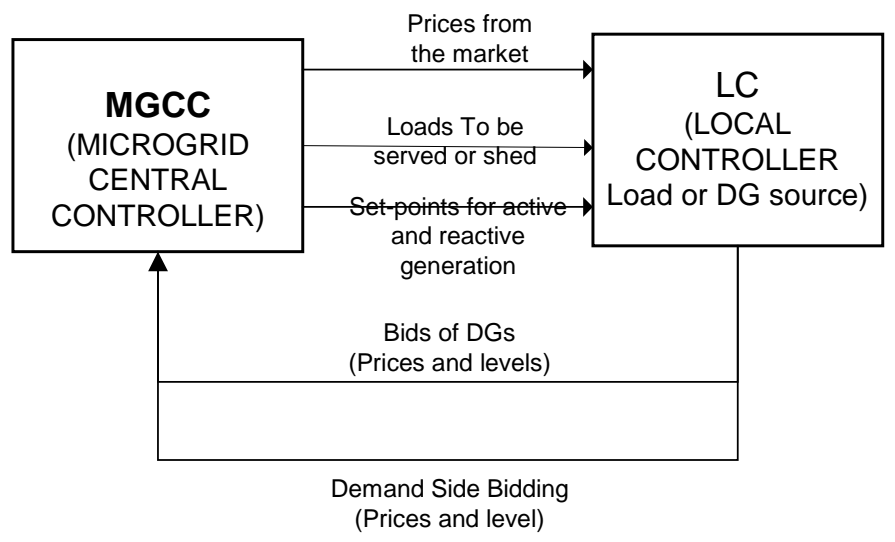

Fig. 2: Information Exchange Diagram

The optimization procedure depends on the Market policy adopted in the Microgrid operation. In [10] a proposed scheme for Demand Side Bidding policy and proposed market polices are explicitly described.

\section{PROBABILISTIC ANALYSIS METHOD}

Probabilistic analysis techniques have been widely used for the estimation of the operating cost of a power system especially when intermittent power sources, such as RES, are installed mainly on a determined and constant tariff scheme[12]. Moreover, probabilistic analysis techniques have been used in order to estimate the voltage profile and the active and reactive power flow in a distribution network when Wind Power penetration is significant [13].

In order to evaluate the financial impact of adding RES such as a wind turbine or a PV in a spot market environment, prices data from the Amsterdam Power eXchange (ApX) spot market [14] for 2003 have been used. The prices are sorted in bins in order to provide a discrete probability distribution function (pdf) of the hourly prices for the whole period examined

Having calculated the distribution of the prices in the open market, the convolution with the power probability distribution function (pdf) of the RES production provides the 
expected revenues for the owner participating in such a spot market or the expected savings for the end users of the Microgrid .The method for calculating the RES power pdf is described in the following subsections.

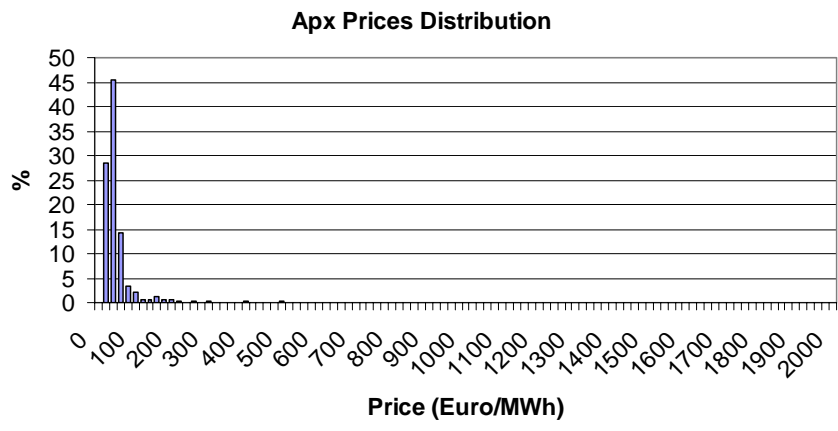

Fig 3 The ApX prices distribution for 2003

\section{A. Wind Power}

For wind power, the wind velocity is a random variable that usually follows a Weibull distribution as described by (2):

$$
\mathrm{f}(\mathrm{v})=\frac{\mathrm{k}}{\mathrm{c}} \cdot\left(\frac{\mathrm{v}}{\mathrm{c}}\right)^{\mathrm{k}-1} \cdot \exp \left(-\left(\frac{\mathrm{v}}{\mathrm{c}}\right)^{\mathrm{k}}\right)
$$

The wind velocity data are converted to wind velocity at the hub height of the wind turbine using equation (3)

$$
\frac{U(Z)}{U(H)}=\left(\frac{Z}{H}\right)^{a}
$$

where $\mathrm{Z}$ is the hub height, $\mathrm{H}$ is the anemometer height and $\alpha$ is the Wind Shear Exponent describing the smoothness of the terrain. For smooth terrain $\alpha$ has values within 0.1 to 0.12 .

The wind power production is calculated using the wind velocity to power characteristic equation[12]. This production is a discrete pdf calculated at the following capacity points, at which the probabilities are calculated :

$$
\begin{aligned}
& \mathrm{C}_{0}=0 \\
& \mathrm{C}_{\mathrm{k}}=\mathrm{k} \cdot \Delta \mathrm{P}, \mathrm{k}=1 . . \mathrm{n}
\end{aligned}
$$

Where $\Delta \mathrm{P}$ is considered equal to $5 \%$ of the nominal capacity therefore $\mathrm{n}$ in our case is equal to 20 .

The possibilities of occurrence for each capacity point are given by the following set of equations :

$$
\begin{gathered}
\mathrm{p}_{0}=1+\Phi(\text { Vcut_in })-\Phi(\text { Vcut_off }) \\
\mathrm{p}_{\mathrm{k}}=\Phi^{-1}\left((2 \mathrm{k}+1) \cdot \frac{\Delta \mathrm{P}}{2}\right)-\Phi^{-1}\left((2 \mathrm{k}-1) \cdot \frac{\Delta \mathrm{P}}{2}\right), \mathrm{k}=1 . \mathrm{n}-1 \\
\mathrm{p}_{\mathrm{n}}=\Phi(\text { Vno min al })-\Phi^{-1}\left((2 \mathrm{n}-1) \cdot \frac{\Delta \mathrm{P}}{2}\right)
\end{gathered}
$$

where $\Phi(\mathrm{x})$ is the cumulative distribution function of the wind speed-Weibull in this case, at the hub height . Vcut in is the velocity above which the WT starts producing active power and vcut_off is the cut-off speed. $\Phi^{-1}(\mathrm{x})$ represents the wind velocity at which the $\mathrm{x}$ wind power production is calculated.

Then using convolution of wind production pdf and spot market prices pdf, the expected revenues for Wind Power can be evaluated.

In order to evaluate the WT production when prices and WT production are positively or negatively correlated, the percentiles at steps of $5 \%$ for both pdfs can be calculated and then the expected revenues are calculated by multiplying the percentile points.

\section{B. Solar Power}

The maximum available power for a PV at a specific site is function of the time, the sun angle and the geographical coordinates of the installation site as described in $[15,16]$. The maximum production of the $\mathrm{PV}$ at $9 \mathrm{am}$ for instance is not equal to the installed capacity of the PV, if the PV is fixed e.g. on the roof of a building. The production of the PV depends also on the clearness index, the ratio of the beam radiation on a horizontal surface to the radiation of the same surface outside the atmosphere. Measurements of clearness index are made at various sites of the world and typical distribution of such measurements are presented in [16]. The clearness index is also associated with diffuse radiation measurements, as described in [17]. Therefore if measurements for diffuse radiation are available like in [18], then the probability distribution function for clearness index can be easily derived. Thus the probability distribution function of the PV production can be derived knowing the clearness index distribution, the maximum available radiation and data about the efficiency of the modules and their surface area.

The methodology followed for evaluating the PV production in a market environment consists of the following steps :

1. Specify the latitude of the place and the installation angle of the PV.

2. Find representative days for each month and the time of sunrise and sunset. Such representative days are given in Table I for Athens, $38^{\circ} \mathrm{N}$.

3. Neglecting cloudiness calculate the maximum solar radiation for the representative day for the specified geometry of the PV using equations (6)-(12).

4. Taking into account the discrete probability of clearness index for the specified site calculate the distribution of the solar radiation for each hour of the representative days.

5. The solar radiation is normalized using the maximum solar radiation result. The normalized result is the fraction of PV production.

6. Convolute the prices probability distribution with the corresponding normalized production for the specific hour and month.

In order to calculate the solar radiation at the specific site for the representative day and hour the following equations are used :

$$
\mathrm{H}(\mathrm{A})=\mathrm{I}_{0} \cdot \mathrm{A}^{\operatorname{cossech}} \cdot \cos \boldsymbol{\theta}+\frac{\mathrm{I}_{0} \cdot \sinh \cdot(1+\cos \mathrm{SL}) \cdot\left(1-\mathrm{A}^{\mathrm{cossech}}\right)}{4 \cdot(1-1.4 \cdot \ln \mathrm{A})}
$$

where $\mathrm{A}$ is the clearness index, SL is the inclination angle of the surface and

$$
\sinh =\sin \phi \cdot \sin \delta+\cos \phi \cdot \cos \delta \cdot \cos \omega
$$

$$
\cos \theta=\sinh \cdot \cos \mathrm{SL}+\cosh \cdot \cos \mathrm{SL} \cdot \cos \left(a-\mathrm{a}^{\prime}\right)
$$




$$
\cos a=\frac{\sinh \cdot \sin \phi-\sin \delta}{\cosh \cdot \cos \phi}
$$

Io the solar constant $\left(1353 \mathrm{~W} / \mathrm{m}^{2}\right)$,

$\varphi$ is the geographical latitude of the site,

$\delta$ is the solar beam inclination angle given by the following equation as described in [19].

$$
\delta=\sin (292-30 \cdot \mathrm{m}-\mathrm{d})
$$

where $m$ is the month and $d$ is the number of the day of the month

$\mathrm{a}^{\prime}$ is the direction of the surface compared to the south (for north hemisphere) or to the north for southern hemisphere.

$\mathrm{h}$ is the solar elevation angle and $\omega$ is the hour angle, that is given by the following equation

$$
\omega=15^{*}(12 \text {-hour })
$$

This equation is modified for the daylight saving time (during April to October) as

$$
\omega=15 *(13 \text {-hour })
$$

All the angles used are in degrees.

The distribution of the spot market prices should be taken at each hour of the day time and for each month in order to take into account the seasonal and hourly variability of PV maximum production

Convolution of PV production and spot markets distribution for the specific hour and month will provides the expected income for the PV investor for each hour and month and thus for the whole year.

\section{CASE STUDY}

It is examined the installation of a wind turbine and a PV in a Microgrid. The consumption of the Microgrid is always considered higher than the RES installed capacity and therefore no energy flow to the upstream distribution network takes place.

\section{A. Wind Power}

Data about the wind velocity distribution at an installation site near the North Sea coast in the Netherlands are used [20].The Weibull distribution at the anemometer height is expressed using (2) and the parameters are $\mathrm{k}=2.1$ and $\mathrm{c}=8.1 \mathrm{~m} / \mathrm{s}$. Measurements are taken at $18.5 \mathrm{~m}$ whereas the hub height is $24 \mathrm{~m}$. The Wind Shear Exponent is considered equal to 0.11 due to the smooth terrain.

It is assumed that a typical WT of $10 \mathrm{~kW}$ will be used. The WT power curve is available in [21], and is also shown in fig 4. This curve is represented by a $3^{\text {rd }}$ order polynomial (13), where $\mathrm{v}$ is the wind velocity in $\mathrm{m} / \mathrm{s}$ and power is the output in $\mathrm{kW}$.The pdf for the specified small WT production is shown in fig 5 .

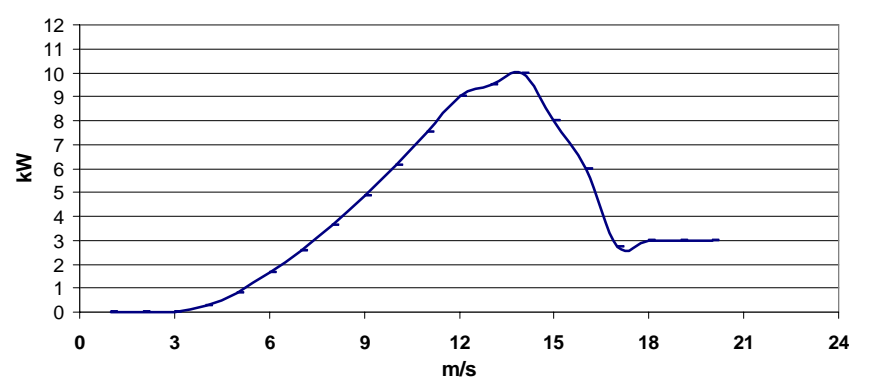

Fig 4 The power curve function of the typical $10 \mathrm{~kW}$ WT [21]

$$
\text { powe(v) }=\left\{\begin{array}{l}
0, \text { if } 0 \leq \mathrm{v}<4 \text { or } \mathrm{v}>54 \\
0.0136 \mathrm{v}^{3}+0.3776 \mathrm{v}^{2}-2.176 \cdot \mathrm{v}+3.732 \text {, if } 4 \leq \mathrm{v} \leq 14.07 \\
-2.39 \cdot \mathrm{v}+43.63, \text { if } 14.07 \leq \mathrm{v} \leq 17 \\
3, \text { if } 17 \leq \mathrm{v} \leq 54
\end{array}\right.
$$

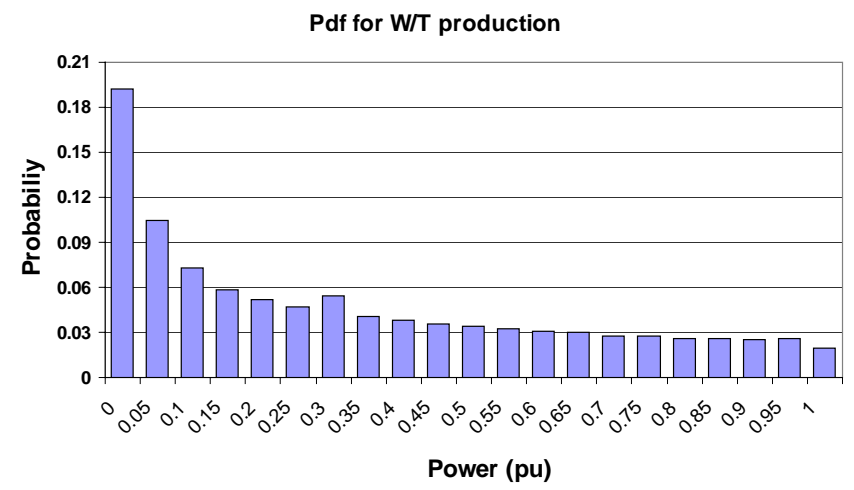

Fig 5 The probability distribution function of wind power production

\section{B. Solar Power}

It has been assumed that the PV installation site follows the solar radiation and clearness index data of the Solar Village in Athens [16,22].The latitude is $38^{\circ} \mathrm{N}$ and we have assumed that the PV faces south directly, therefore $\mathrm{a}^{\prime}=0^{\circ}$ and the installation angle is $\mathrm{SL}=38^{\circ}$, equal to the latitude of the installation place.The installed PV capacity is $1 \mathrm{kWp}$. The representative days used for calculating the maximum production available according to the methodology described in section III are given in Table I : The clearness index for the whole year is shown in fig. 6

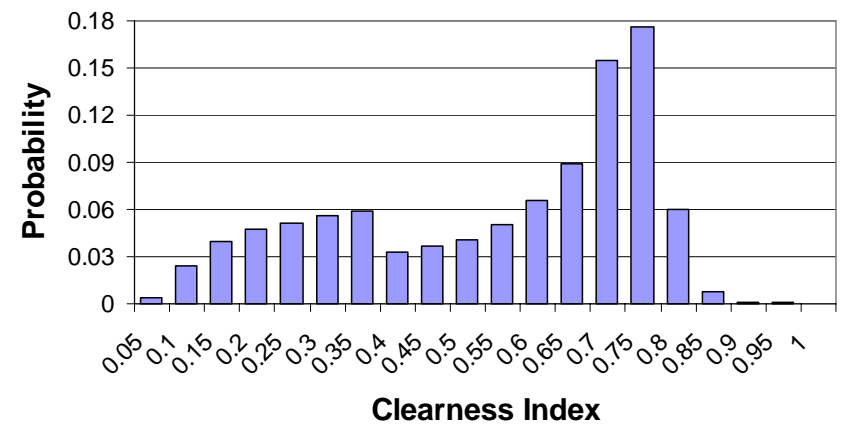

Fig 6 The clearness index probability distribution function 
TABLE I

CHARACTERISTIC DAYS FOR EACH MONTH [15]

\begin{tabular}{|l|l|l|l|}
\hline Month & Day & Sunrise & Sunset \\
\hline January & 17 & 7.39 & 17.32 \\
\hline February & 16 & 7.14 & 18.05 \\
\hline March & 16 & 6.35 & 18.33 \\
\hline April & 15 & 6.50 & 20.01 \\
\hline May & 15 & 6.15 & 20.28 \\
\hline June & 11 & 6.02 & 20.47 \\
\hline July & 17 & 6.16 & 20.46 \\
\hline August & 16 & 6.41 & 20.17 \\
\hline September & 15 & 7.07 & 19.33 \\
\hline October & 15 & 7.34 & 18.48 \\
\hline November & 14 & 7.01 & 17.17 \\
\hline December & 11 & 7.32 & 17.06 \\
\hline
\end{tabular}

Using equation (6) and the clearness index pdf, the PV production pdf can be derived for each month and each hour. A typical example at 11:00 of the representative day of June is shown in fig 7 .

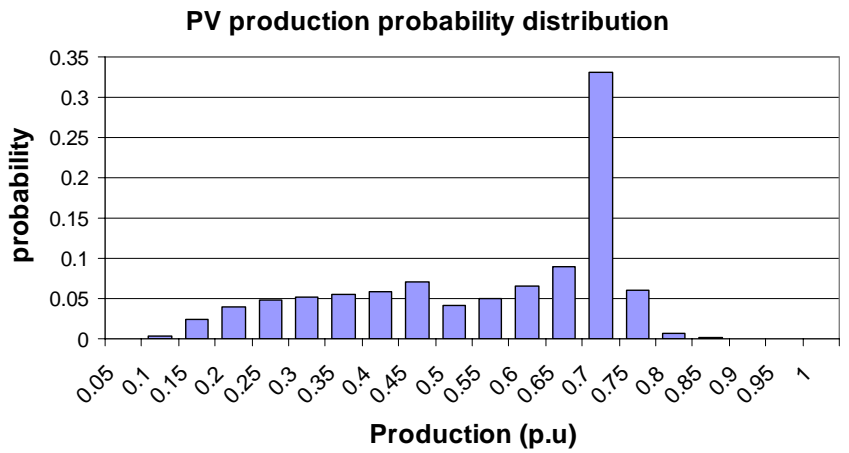

Fig 7 The probability distribution function of PV production at 11:00 am of the characteristic day of June

Convolution of spot market prices pdf and PV pdf for each hour and month provides with expected income for the whole year.

\section{RESULTS}

\section{A. Wind Power}

The annual production of the WT at the installation site is expected to reach $28672 \mathrm{kWh}$ and the expected income for the WT owner with uncorrelated prices and wind production $1469.3 €$ or $5.1 € \mathrm{ct} / \mathrm{kWh}$. If the production is assumed positively correlated with the prices of the spot market, this means that the production is high when the prices are high, the expected income reaches $5248.43 €$. On the contrary, when prices of the spot market and the wind power production are negatively correlated, which means that we have high prices at periods of low production, then the income is $527.85 €$. In the former case the value of the $\mathrm{kWh}$ is $18 € \mathrm{ct} / \mathrm{kWh}$, while in the latter only $1.8 € \mathrm{ct} / \mathrm{kWh}$.

Using Greek tariff scheme for islands, the expected income would have been $2233.55 €$ if prices and wind velocity are uncorrelated.

\section{B. Solar Power}

Using the methodology described in Section III.B the following results have been derived for each month of 2003 .
TABLE II

MONTHLY REVENUES AND PRODUCTION FOR THE PV INSTALLATION

\begin{tabular}{|l|c|c|c|}
\hline \multicolumn{1}{|c|}{ Month } & Revenues $(€)$ & $\begin{array}{c}\text { Production } \\
(\mathrm{kWh})\end{array}$ & $\begin{array}{c}\text { Average } \\
\text { Price } \\
(€ \mathrm{ct} / \mathrm{kWh})\end{array}$ \\
\hline January & 5.4 & 63.34 & 8.52 \\
\hline February & 3.3 & 72.72 & 4.54 \\
\hline March & 4.14 & 102.68 & 4.03 \\
\hline April & 4.36 & 116.88 & 3.73 \\
\hline May & 5.7 & 132.51 & 4.3 \\
\hline June & 15.48 & 132.68 & 11.66 \\
\hline July & 9.88 & 134.91 & 7.33 \\
\hline August & 24.62 & 127.09 & 19.37 \\
\hline September & 6.57 & 92.41 & 7.11 \\
\hline October & 9.41 & 80.83 & 11.65 \\
\hline November & 5.82 & 60.92 & 9.55 \\
\hline December & 2.81 & 52.56 & 5.34 \\
\hline
\end{tabular}

The expected production is $1170 \mathrm{kWh}$ while the expected income is $97.49 €$. The average price for the whole year is $8.34 € \mathrm{ct} / \mathrm{kWh}$. If the Greek feed-in tariff scheme is followed for island systems then the expected revenues would be 91.14 $€$.

\section{Pay-back analysis}

Having calculated the expected income for the RES installation the pay back period for the installation can be calculated using equation (14).

$$
\text { Ann_Income }=\frac{i \cdot(1+i)^{n}}{(1+i)^{n}-1} \cdot \text { InsCost }
$$

$\mathrm{n}$ is the depreciation time, $\mathrm{i}$ is the discount rate, Ins Cost is the installation cost and the Ann_Income is the expected income.

Typical Installation costs for a small wind turbine is $2500 € / \mathrm{kW}$ and for PV $7000 € / \mathrm{kW}$ [23]. Different subsidy systems can be examined, such as different percentages of subsidies in the capital investment. The one used in our study is $30 \%$ subsidy of the capital investment for Wind turbine installation and the $50 \%$ subsidy of the PV installation cost, as the Greek "Competitiveness" program [24] foresees for such installations.

The maximum interest rate given in (15) for paying back the investment is the ratio of annual income to the investment cost ,that is the limit to infinitive for $n$ of equation (14)

$$
i^{\text {MAX }}=\frac{\text { Ann _ Income }}{\text { InsCost }}
$$

The results are summarized in Table III for wind power and in Table VII for PV installations.

\section{1) Wind power}

In Table IV the years for paying back the investment cost with $7.5 \%$ interest rate are shown. If any number in Table III is smaller than $7.5 \%$ then the respective case cannot be paid back. Such is the case with negatively correlated prices and the case of uncorrelated prices without any subsidy.

In Table $\mathrm{V}$ the interest rate for paying back within 12 years is summarized, while the necessary subsidy scheme for 10 years period and $7.5 \%$ interest rate is summarized in Table VI. 
TABLE III

MAXIMUM INTEREST RATE FOR PAY-BACK OF THE INVESTMENT

\begin{tabular}{|l|c|c|c|c|}
\hline & $\begin{array}{c}\text { Not } \\
\text { Correlated }\end{array}$ & $\begin{array}{c}\text { Positively } \\
\text { Correlated }\end{array}$ & $\begin{array}{c}\text { Negatively } \\
\text { Correlated }\end{array}$ & $\begin{array}{c}\text { Greek } \\
\text { tariff } \\
\text { scheme }\end{array}$ \\
\hline $\begin{array}{l}\text { Without } \\
\text { subsidy }\end{array}$ & $5.87 \%$ & $21 \%$ & $2.11 \%$ & $8.9 \%$ \\
\hline $\begin{array}{l}\text { With } \\
\text { subsidy }\end{array}$ & $8.43 \%$ & $30 \%$ & $3.01 \%$ & $12.7 \%$ \\
\hline
\end{tabular}

TABLE IV

YEARS For PAY-BACK WIND POWER AND 7.5\% RATE

\begin{tabular}{|c|c|c|c|}
\hline & $\begin{array}{c}\text { Not } \\
\text { Correlated }\end{array}$ & $\begin{array}{c}\text { Positively } \\
\text { Correlated }\end{array}$ & $\begin{array}{c}\text { Greek tariff } \\
\text { scheme }\end{array}$ \\
\hline $\begin{array}{c}\text { Without } \\
\text { subsidy }\end{array}$ & Not paid back & 6.11 & 25.3 \\
\hline $\begin{array}{c}\text { With } \\
\text { subsidy }\end{array}$ & 30.94 & 4 & 12.25 \\
\hline
\end{tabular}

TABLE V

INTEREST RATE For PAY-BACK PERIOD OF 12 YeARS

\begin{tabular}{|l|c|c|c|}
\hline & $\begin{array}{c}\text { Not } \\
\text { Correlated }\end{array}$ & $\begin{array}{c}\text { Positively } \\
\text { Correlated }\end{array}$ & $\begin{array}{c}\text { Greek tariff } \\
\text { scheme }\end{array}$ \\
\hline $\begin{array}{l}\text { Without } \\
\text { subsidy }\end{array}$ & Not paid back & $18.1 \%$ & $1.09 \%$ \\
\hline $\begin{array}{l}\text { With } \\
\text { subsidy }\end{array}$ & $0.1 \%$ & $28.5 \%$ & $7.26 \%$ \\
\hline
\end{tabular}

TABLE VI

NeCESSARY SubSIDY SCHEME For 10 YeARs PAy-BACK PERIOD AND INTEREST RATE, $7.5 \%$

\begin{tabular}{|c|c|c|c|}
\hline $\begin{array}{c}\text { Not } \\
\text { Correlated }\end{array}$ & $\begin{array}{c}\text { Positively } \\
\text { Correlated }\end{array}$ & $\begin{array}{c}\text { Negatively } \\
\text { Correlated }\end{array}$ & $\begin{array}{c}\text { Greek tariff } \\
\text { scheme }\end{array}$ \\
\hline $58.92 \%$ & $0 \%$ & $85.51 \%$ & $38.67 \%$ \\
\hline
\end{tabular}

The price for WT production for paying back within 10 years and interest rate $7.5 \%$ should be $8.9 € \mathrm{ct} / \mathrm{kWh}$ with $30 \%$ subsidy. If the cost for small wind turbines is reduced to $1436.1 € / \mathrm{kW}$ then the calculated value of $\mathrm{kWh}$ produced with the existing subsidy scheme would be sufficient for the timely pay back of the investment.

Using the estimations of European Wind Energy Association (EWEA)[25] the installation cost for onshore wind parks is $900-1100 € / \mathrm{kW}$, and assuming annual discount rate of $7.5 \%$ the payback period is $12.66-18.3$ years. With $30 \%$ subsidy this is 7.53 years to 9.95 years. For costs of large wind turbines no subsidy will be required for the timely pay-back of the investment with the expected value of Wind power production.

\section{2) Solar power}

The results from payback analysis are summarized in the following tables

TABLE VII

MAXIMUM INTEREST RATE FOR PAY-BACK OF THE INVESTMENT

\begin{tabular}{|l|c|c|}
\hline & Not Correlated & $\begin{array}{c}\text { Greek tariff } \\
\text { scheme }\end{array}$ \\
\hline Without subsidy & $1.39 \%$ & $1.3 \%$ \\
\hline With subsidy: & $2.7 \%$ & $2.6 \%$ \\
\hline
\end{tabular}

According to the above Table VII solar power cannot be paid back with interest rate of $7.5 \%$. The minimum pay-back time is 36 years with interest rate $0 \%$

TABLE VIII

PAY-BACK PERIOD FOR ZERO INTEREST RATE IN YEARS

\begin{tabular}{|l|c|c|}
\hline & $\begin{array}{c}\text { Not } \\
\text { Correlated }\end{array}$ & Greek tariff scheme \\
\hline Without subsidy & 71.8 & 76.8 \\
\hline With subsidy & 35.9 & 38.4 \\
\hline
\end{tabular}

The necessary subsidy scheme for 10 years period and $7.5 \%$ interest rate is summarized in Table IX.

TABLE IX

NeCESSARy SubSidy SCHEME For 20 YeARs PAy-BACK PERIOD AND INTEREST RATE, $7.5 \%$

\begin{tabular}{|c|c|}
\hline Not Correlated & Greek tariff scheme \\
\hline $85.71 \%$ & $86.71 \%$ \\
\hline
\end{tabular}

The price for paying back a PV installation within 20 years with $7.5 \%$ is $29.34 € \mathrm{ct} / \mathrm{kWh}$. with $50 \%$ subsidy and 58.68 $€ c t / k W h$. without any subsidy. The Greek subsidy scheme would suffice for the calculated value of the PV produced $\mathrm{kWh}$, if the PV installation cost is reduced to $1990 € / \mathrm{kW}$.

\section{CONCLUSIONS}

Probabilistic analysis helps in estimating the expected income for solar and wind installations, the tariff scheme or the subsidy percentage when the energy is bought from a power exchange market. If Microgrids are expected to exchange power at the open market prices then such analysis can help in evaluating the impact of operating RES during the whole year. Timely pay-back for the installations would be performed if there is some kind of subsidy, either in the prices or in the installation cost. If the subsidy scheme is insufficient or no subsidy is available, the operating cost for the Microgrid is increased. This increase depends on the size of the Microgrid. It should be noted however, that parameters like increased reliability or improved voltage profile should be also quantified and taken into consideration.

Further analysis can be made considering energy storage and be its impact in increasing the correlation between energy prices and wind or solar power production

\section{REFERENCES}

[1] R. Lasseter, A. Akhil, C. Marnay, J. Stephens, J. Dagle, R. Guttromson, A. Meliopoulos, R. Yinger and J. Eto, "White Paper on Integration of Distributed Energy Resources. The CERTS MicroGrid Concept.," Consortium for Electric Reliability Technology Solutions (CERTS), CA, Tech. Rep. LBNL-50829, Apr. 2002.

[2] MICROGRIDS - Large Scale Integration of Micro-Generation to Low Voltage Grids", EU Contract ENK5-CT-2002-00610, Technical Annex, May 2002, Available: http://microgrids.power.ece.ntua.gr

[3] I.Skotinos,N.Hatziargyriou,A.Dimeas,A.Tsikalakis,'Economic Evaluation of Energy Production Systems with high wind power penetration,application to the Greek National Interconnected system.”. presented at the 2004 EWEA Confererence,London

[4] N.Hatziargyriou A G. Tsikalakis, A.Dimeas, D,Georgiadis, A.Gigantidou, J Stefanakis, E. Thalassinakis, "Security and Economic 
Impacts of High Wind Power Penetration in Island Systems", presented at the 2004 Cigre Session,Paris ,August 2004

[5] Federal Ministry of Environment. Nature Conservation and Nuclear Safety ,'Act on Granting Priority to Renewable Energy Sources(Renewable Energy Sources Act)',Berlin, March 2002, Available on-line www.bmu.de/files/res-act.pdf

[6] M.Bechberger, D.Reiche, "Renewable energy policies in an enlarghed European Union, RE in EU-28",Refocus Magazine, Issue September/October 2003

[7] The new Electricity Trading Arrangements-A review of the First Three Months, Ofgem, August 2001,Available www.ofgem.com

[8] Report to DTI on the Review of the Initial Impact of NETA on Smaller Generators, Ofgem, August 2001, www.ofgem.com

[9] T.Ackermann, G.Andersson, L.Soder ,"Overview of government and market driven programs for the promotion of renewable power generation", Renewable Energy Journal Vol 22, ,2001, pp 197-204

[10] A.Tsikalakis, N.Hatziargyriou, "Economic Scheduling Functions of a Micro-grid participating in Energy Markets", to be presented at the CIGRE International Symposium on "Power Systems with Dispersed Generation: technologies, Development and Performances", Athens 13th-16th April 2005.

[11] A.Dimeas and N.D. Hatziagyriou, "A MultiAgent system for MicroGrids", presented at the IEEE PES General Meeting, Denver, CO, June 6-10, 2004, paper -PESGM2004-001244

[12] A.G. Bakirtzis, P.S. Dokopoulos, E.S. Gavanidou, M. A. Ketselidis, A probabilistic costing method for the evaluation of the performance of grid-connected wind arrays, IEEE Transactions on Energy Conversion, Vol 4,No1, pp34-40,March 1989

[13] N.D. Hatziargyriou,T.S.Karakatsanis,M.Papadopoulos,"Probabilistic Load Flow in Distribution Systems Containing Dispersed Wind Power Generation", IEEE Trans. On Power Systems ,Vol 8,No 1,February 1993,pp159-165

[14] ApX Historical Data, available on-line :http://www.apx.nl

[15] S.Yamamoto, J.S.Park ,M.Takata,K.Sasaki,T.Hashimoto, "Basic Study on the prediction of solar irradiation and its application to photovoltaicdiesel hybrid system", Solar Energy Materials \& Cells,Vol 75, ,2003, pp 577-584

[16] N.Papageorgiou, D.Prapas, B.Sotiropoulos, "Evaluation of solar irradiation measurements of Solar Village 3", In Proc of the $4^{\text {th }}$ National Conference on RES, Xanthi, October 1992 (in Greek),pp1-8

[17] J.F. Orgill, K.G.T. Hollands, "Correlation Equation for Hourly Diffuse Radiation on a Horizontal Surface",J. Solar Energy Vol 19,No 4,pp357359,1977

[18] M.Hjazin The diffuse fraction of hourly solar radiation for Amman/Jordan, Renewable Energy, Vol. 13, No. 2, , 1998, pp. 249 253

[19] The Solar radiation in Salonica and its relation with the hours of solar irradiation, H.Sahsmanoglou, T.Makroyiannis, In Proc of the $3^{\text {rd }}$ National Conference on RES, Salonica, November 1988 (in Greek) pp35-45

[20] P. Coelinghal, A.J.M. van Wijkal, A.A.M. Holtslagb Journal of wind Engineering and Industrial Aerodynamics Volume 73 1998,pp 125-144

[21] Available www.bergey.com

[22] G. Tsilingiridis and V. Sotiropoulos, Three-year measurements of ambient and indoor air temperatures in Solar Village-3, Athens, Greece Energy and Buildings, Volume 28, Issue 2, October 1998,pp 127-136

[23] G. Pepermans, J.Driesen, D. Haeseldonckx, R. Belmaans, W. D'haeseleer, "Distributed generation: definition,benefits and issues" J.Energy Policy, Volume 33, Issue 6, April 2005, pp 787-798.

[24] $3^{\text {rd }}$ Operational program "Competitiveness", Available on-line, www.antagonistikotita.gr

[25] European Wind Energy Association (EWEA),available www.ewea.org

\section{BIOGRAPHIES}

Antonis G. Tsikalakis was born in Athens, Greece in 1979. He received his diploma in Electrical and Computer Engineering from NTUA. He is currently a Ph.D. student at Electrical and Computers Engineering Department of NTUA. His research interests include optimization of power system operation, Dispersed Generation and energy storage. Mr. Tsikalakis is a student member of IEEE and member of the Technical Chamber of Greece

Nikos D. Hatziargyriou was born in Athens, Greece. He received the Diploma in Electrical and Mechanical Engineering from NTUA and MSc and
$\mathrm{PhD}$ degrees from UMIST, Manchester, UK. He is professor at the Power Division of the Electrical and Computer Engineering Department of NTUA. His research interests include Dispersed and Renewable Generation, Dynamic Security Assessment, and application of Artificial Iintelligence Techniques to power systems. He is senior IEEE member, member of CIGRE SCC6 and the Technical Chamber of Greece. 